\title{
JUDICIAL TRENDS IN GRATUITOUS ASSIGNMENTS TO AVOID FEDERAL INCOME TAXES
}

\author{
RALPH S, RICEं
}

Taxpayers in the higher income brackets often seek to redirect their income to objects of their bounty in order to minimize the progressive features of the tax. Their efforts have resulted in one of the most untidy areas in tax jurisprudence. Housewives and infants have become operating partners, thereby sharing (before taxes) in the paterfamilial profits, in almost every variety of commercial enterprise susceptible of operation by a partnership. The owner of property who gives it to another and then leases it back; the earner who assigns the rewards for his labors either before or after his services are performed; the entrepreneur who assigns his claims under long-term contracts; and the author or inventor assigning literary or patent rights-all of these may be engaged in efforts essentially similar in purpose. Nor are these all. The person who assigns income rights-such as retirement benefits-arising from past services; the owner who transfers portions of operating interests in mineral operations, whether such interests be royalty or realty; and the person who transfers property to a trust but retains substantial interests in the trust likewise may be seeking to minimize tax by redirecting income. Some devices are of early origin, but there is a constant flow of newer stratagems as the ingenuity of taxpayers reaches ever higher levels of expression.

Legislative reaction to many of the problems raised by these gratuitous assignments has been both sporadic and inconsistent: the Revenue . Ict of 1954 ignores them for the most part. Judicial response likewise has been uneven and, to a degree, illogical. Pressures on the Commissioner and the courts to protect the public revenue have frequently resulted in ad hoc solutions to tax avoidance problems, which in turn have given rise to an abundance of conflicting generalizations. Justice Holmes once announced that an anticipatory assignment of earnings could not minimize federal income tax liability because fruits may not be "attributed to a different tree from that on which they grew." The metaphor has been substituted for rational analysis by courts and commentators to the point where a critic in this area frequently cannot see the forest for the fruit trees. Metaphors lead nowhere: the number and extent of the tax avoidance devices that have been employed here make a more analytical approach imperative if rational results are to be achieved.

If the judicial responses to the problem of gratuitous assignments have a rational basis, it needs to be stated. The data from which the incidence of tax liability must be predicted should not be merely a scattering of decisions based on no common theory or-what is worse-based on every imaginable theory for cases that are essentially the same.

$\dagger$ Professor of Law, University of California, Los Angeles.

1. Lucas v. Earl, 281 U.S. 111, 115 (1930). 


\section{The Judicial Problem in Cases Involving Gratuitous Assignments}

To begin at the beginning, we must remind ourselves that no federal income tax is ever payable except as the Internal Revenue Code requires it, and in the usual case that requirement is imposed because the person taxed has "income" under section 61 of the Code. The section does not, however, inform us as to when income is taxed to some person other than the actual recipient. The answer to this question must be sought by the courts in most cases without guidance from the statute itself.

There is no question but that in some cases a person should not be allowed to avoid income taxation by gratuitously assigning a part of his income, or property from which income arises, to another. Yet one can legitimately transfer property and income to another, and there is a point at which the recipient must be considered the person to be taxed upon the income that is legally his. There are innumerable gradations between the two extremes: the problem of the courts is to find a test by which it can be determined on which sicle of the line a given case must fall. We cannot say whether any test is adequate until we know the reason for the distinction between the two kinds of cases-a reason that must be sought in the broad aims of any structure of taxation. These aims are two: first, the tax plan must be administratively feasible, in the sense that it must produce a maximum of revenue with a minimum of effort; and second, it must be equitable, in the sense that transactions and taxpayers essentially similar must be treated similarly. Thus in some cases the taxpayer who has technically assigned his income is in reality so little different from one who has not tried to assign it that it would frustrate the basic aims of the tax law to recognize the assignment.

It is one thing to agree that some more obvious forms of anticipatory assignments should be ignored for tax purposes; it is something else again to draw a line establishing the area of the limitation. The ethical values according to which each jurist presumably draws the line dictated by his conscience and his view of the public needs can scarcely be standardized. And even when agreement is reached on where the line should be drawn in a specific case, there remains the problem of expressing general principles to control other decisions. This in turn is difficult when the only keys for interpreting the statute are the requirements of workability and fairness.

The result is that the decisions actually fall far short of furnishing criteria by which taxpayer or Commissioner may determine the extent to which a person may reduce his taxes by redirecting income to another. The several Supreme Court decisions dealing with the problem reflect much uncertainty both as to the point where the lines are to be drawn and as to the tests to be used in determining on what side of the line a given arrangement falls. In many decisions the subject is discussed generally and reference is made to a number of rules of potentially general application, so that it is impossible to single out the particular doctrine, or accurately to reconstruct the analysis, on which the Court relied. Some of these decisions seem purposely vague. In 
other cases principles are enunciated that seem reasonably applicable in some circumstances and obviously inappropriate in others.

The following comments are an attempt to evaluate the principal doctrines and decisions in this area-most of them utterances of the Supreme Courtin terms of the basic aims of the tax law. Four principal doctrines will be considered:

1. The concept that one who assigns to another the right to receive income is taxable with respect to that income because he received material or non-material satisfactions from the transfer. This doctrine is inadequate because it extends taxation of the donor too far.

2. The theory that when "ownership" of "property" is transferred, the income arising therefrom cannot be taxed to the donor. This doctrine is inadequate because it restricts taxation of the donor too narrowly.

3. The doctrine that income is taxed to him who earns it. This principle seems logical and has been reasonably definitive in its application.

4. The concept that where property or a right to income therefrom is transferred but the donor retains control over the payment of the income or control over the management and use of the corpus, the transfer is not effective to redirect income from donor to donee for tax purposes. This doctrine, supplemented by the preceding rule, establishes a proper theoretical basis for controlling anticipatory assignments made for the purpose of avoiding federal income taxes.

\section{Donor's Satisfactions as a Basis for Taxing the Donor}

The thought is frequently expressed that a person who obtains material or non-material satisfaction from transferring to another his right to income should be taxed as if payments were made to him, even where payments are in fact made to the other. The concept stems from Hclvcring w. Horsl, - where the Supreme Court held that a taxpayer retaining a bond but transferring interest coupons thereon was taxable with respect to income from the coupons:

"The taxpayer has equally enjoyed the fruits of his labor or investment and obtained the satisfaction of his desires whether he collects and uses the income to procure those satisfactions, or whether he disposes of his right to collect it as the means of procuring them. . . .

"Such a use of his economic gain, the right to receive income, to procure a satisfaction ... would seem to be the enjoyment of the income whether the satisfaction is the purchase of goods at the corner grocery, the payment of his debt there, or such non-material satisfactions as may result from the payment of a campaign or community chest contribution, or a gift to his favorite son .... The enjoyment of the economic benefit accruing to him by virtue of his acquisition of the coupons is realized as completely as it would have been if he had collected the interest in dollars and expended them for any of the purposes named."3

2. 311 U.S. 112 (1940).

3. Id. at 117. The "flow of satisfactions" test elaborated here was bascd on langunge in Burnet v. Wells, 289 U.S. 670 (1933). It is questionable whether the principles there enunciated should be applied elsewhere. In the $W$ clls case, it was held only that the 
Substantially the same view is expressed in the concept that the right to dispose of income is equivalent to ownership of it. ${ }^{4}$ The right to dispose of income obviously is of value only to the extent that satisfactions may be obtained thereby. Exercising the right to dispose of income brings satisfactions, and the enjoyment of those satisfactions is the equivalent of receiving taxable income. Either doctrine means in effect that income should be taxable to one who is entitled to it but directs payments to another; or stated otherwise, that where one disposes of a right to receive income he will nevertheless be taxed with its receipt.

The rule presents substantial problems. As was pointed out in Horst, income is frequently attributed to a taxpayer where it is applied to the discharge of his obligations. To the extent that an obligation is discharged for a valuable consideration there is no doubt as to the propriety or universality of this rule. However, when gifts of property are involved there is a basic inconsistency in the results of the cases. An example will illustrate the point. Assume a case where a father owns Blackacre, which has appreciated in value. He has the right to sell Blackacre and thus realize the accretion in value. If he does so, he will have taxable income. He also has the right to dispose of the accretion in value by giving Blackacre away, and in this sense has the right to dispose of an item which, when realized, would be income. But in the usual case, we do not tax the increment to him simply because he gave it away, whether he receives a "satisfaction" from the gift or not." Moreover, it may be said that the father had a right to rentals from Blackacre, and has disposed of that right to income along with the property. But it would seem that having given Blackacre away, he should no longer be taxed on the rentals, notwithstanding that payment of the income to the son provides a satisfaction to the father. And so it was held by the Supreme Court in Helvering $v$. Stuart ${ }^{7}$ that a father making such a transfer in an irrevocable trust for the benefit of his children was not taxable on income received by the trustee solely because he had once owned the property. This view has been adopted in regulations promulgated by the Commissioner. ${ }^{8}$

The Court's attempt in the Stuart case to harmonize its decision with the rationale of the Horst case is expressive of a confusion seldom equaled in Supreme Court history. The Court first observed that it was being invited to hold that trust income was taxable to the grantor of the corpus simply on the

satisfaction obtained by the donor was sufficient so that Congress could constitutionally tax him. This single decision is far from authorizing the holding that the law does tax the assignor of income simply because receipt thereof by the assignee would caluse the donor satisfaction.

4. See Harrison v. Schaffner, 312 U.S. 579, 580 (1941).

5. See, e.g., Old Colony Trust Co. v. Commissioner, 279 U.S. 716 (1929), and cases discussed in notes 58 and 79 infra. For the current law respecting payment by a lessec of the lessor's taxes, see INT. REv. CoDE of 1954, § 110.

6. See discussion at pp. 1006-08 infra.

7. 317 U.S. 154 (1942).

8. U.S. Treas. Reg. 118, §39.22(a)-21 (1953). 
basis that use of the income "would satisfy the normal desire of a parent ta make gifts to his children." It declined this invitation, partly on the ground that "no act of Congress manifests such an intention." 10 This argument seems bootless : to no greater extent did any act of Congress manifest an intention to tax the donor in many other cases where he was in fact taxed. The Court then observed that "economic gain realized or realizable by the taxpayer is necessary to produce a taxable income ...."11 But such an argument proves nothing. For example, gain was never realized (in the sense of becoming accrued or paid to the person taxed) in the Horst case itself, and the donor there was taxed nonetheless. Apparently one criterion for determining when gain is realized by a donor was to be used in Horst and the cases it cites, while another concept is to be used in the Stuart case: exactly what those concepts are or why there should be a distinction is left to the imagination of the reader. Next the Court said that in Horst it had observed that there the donor had the "use [realization] of his economic gain." But it was not explained in just what respect the same observation was not equally applicable in the Stuart case, though it was suggested that in none of the earlier cases "had the taxpayer really disposed of the res which produced the income."12 This would seem to throw us into the so-called "property" concept respecting redirection of income. As will be shown, this concept has frequently been rejected by the Supreme Court, and seems unsound in any event. ${ }^{13}$ Finally, the Court observed, citing the Horst case, that "the 'non-material satisfactions' (gifts-contributions) of a donor are not taxable as income."14 This observation is incomprehensible. The Horst case in fact held just the contrary. All in all, it must be said that the Stuart decision expresses a result without a reason, but that the result unquestionably represents current law.

All we know from Horst and Stuart is that sometimes a flow of satisfactions results in taxability to a donor and sometimes it does not. ${ }^{15} 1 \mathrm{IT}^{\circ}$ must still search for a doctrine that will rationalize the disparate results of the cases.

\section{Transfer of "Ownership" of "Property" as a Ground for Taxing THE DONEE}

Another elementary but elusive concept is that a transfer of "ownership" of "property" is effective to eliminate future taxation of the donor with respect

9. Helvering v. Stuart, 317 U.S. 154, 168 (1942).

10. Ibid.

11. Ibid.

12. Ibid.

13. See pp. $995-1000$ infra.

14. Helvering v. Stuart, 317 U.S. 154, 168 (1942).

15. While the doctrine will not stand analysis, there has been occasional reference to it since the Horst case. See, e.g., Byers v. Commissioner, 199 F.2d 273 (8th Cir. 1952); Acer Realty Co. v. Commissioner, 132 F.2d 512 (8th Cir. 1942). But sce Estate of Holmes, 1 T.C. 508 (1943). Similar emphasis on the flow of satisfactions enjoyed by the donor is found in some cases where a donor has conveyed property in trust for a heneficiary. See, e.g., Commissioner v. Bateman, 127 F.2d 266 (1st Cir. 1942); Commissioner 
to income from that property. It is important to note that this doctrine hats two facets. One facet is seen in cases where a transferor gives away title to a corpus - ownership of the exploited property. It is not infrequently said in this situation that the taxable income follows the ownership of the property. ${ }^{10}$ in this sense, ownership means passage of legal title. This concept conflicts with the doctrine that where property is transferred from one person to another and the donor retains substantial "control" over it, subsequent income is taxed to the donor. This facet of the "property" concept will be considered in connection with the "control" doctrine. ${ }^{17}$

The other facet of the "ownership" concept is the view that where property that is itself essentially a right to income is transferred, the income is taxed to the donee even though the donor retains the corpus from which the income arose. Such a case might arise where an individual licenses a patent and transfers the license, with his right to receive payments under it, while retaining the patent. It has been suggested that the donor should be relieved of tax because he transferred property in the sense that he completely gave up dominion over the license. ${ }^{18}$

The leading exposition of this doctrine is in Blair $v$. Commissioner, ${ }^{10}$ where a life beneficiary of a trust assigned a portion of his interest to his children, to be paid to them annually for the duration of his interest. The Court concluded that this assignment was effective to redirect income from the donor to the donee on the ground that the "assignment of the beneficial interest is not the assignment of a chose in action but the 'right, title and estate in and to property." "20 The Court thought that since the assignee became "the owner of an equitable interest in the corpus of the property," the income therefrom was properly taxable to $\mathrm{him}^{21}$

Subsequent decisions belie the clarity and simplicity of this formulation in Blair, and some cases specifically reject the concept. Even prior to the Blair decision, the Supreme Court had considered a case in which taxpayer assigned half his partnership interest to his wife. The taxpayer urged that the assignment to his wife was of one-half the "corpus" of his interest and that this "corpus" produced the income in question. The Court observed that "the characterization does not aid the contention."22 The Blair rationale was ignored in a case where a taxpayer assigned for one year his beneficial interest

v. Wilson, 125 F.2d 307 (7th Cir. 1942) ; Mairs v. Reynolds, 120 F.2d 857 (8th Cir. 1941) ; Whitely v. Commissioner, 120 F.2d 782 (3d Cir. 1941).

16. Pearce v. Commissioner, 315 U.S. 543, 554 (1942) ; Blair v. Commissioner, 300

U.S. 5,12 (1937).

17. This doctrine is discussed at pp. 1013-16 infra.

18. See, e.g., Lewis v. Rothensies, $61 \mathrm{~F}$. Supp. 862 (E.D. Pa. 1944), aff'd par curiam, 150 F.2d 959 (3d Cir. 1945). See also cases cited in notes 29 and 30 infra.

19. 300 U.S. 5 (1937).

20. Id. at $13-14$.

21. Id. at 13 .

22. Burnet v. Leininger, 285 U.S. 136, 141 (1932). See aiso Burnet v. Wells, 289 U.S. 670 (1933). 
in a trust. The Commissioner taxed him on the income from the trust for that year, over his objection that he had parted with the ownership of property when he made the assignment. The Supreme Court observed that the taxpayer

"rests his case on technical distinctions affecting the conveyancing of equitable interests. It is said that since by the assignment of trust income the assignee acquires an equitable right to an accounting by the trustee which, for many purposes, is treated by courts of equity as a present equitable estate in the trust property, it follows that each assignee in the present case is a donee of an interest in the trust property for the term of a year and is thus the recipient of income from his own property. ... $[W]$ e think that the operation of the statutes taxing income is not dependent upon such 'attenuated subtleties'. ..."23

In another case subsequent to Blair the "ownership" approach was even more emphatically rejected. Here a donor was taxed on income from property that he had put in trust. Again the taxpayer claimed that the transier was effective to redirect income because he had ceased to be the owner of property after the transfer. The Court observed:

"Technical considerations, niceties of the law of trusts or conveyances, or the legal paraphernalia which inventive genius may construct as a refuge from surtaxes should not obscure the basic issue. That issue is whether the grantor after the trust has been established may still be treated, under this statutory scheme, as the owner of the corpus."2s

Leaving authority to one side, the deficiencies of the "ownership" doctrine are obvious. For a basic aim of the tax structure is equitable distribution of the $\operatorname{tax}$ burden, and feudal property concepts concerning "ownership" of "property" are irrelevant in such a context. A taxpayer seeking unfairly to

23. Harrison v. Schaffner, 312 U.S. 579, 580-S1 (1941). The decision was based on the "control" theory considered at pp. 100S-16 infra. It should be noted, however, that the Court did not discountenance the result in the Blair case, although it was invited to do so.

24. Helvering v. Clifford, 309 U.S. 331, 334 (1940). Lower courts have made comments to the same effect. For example, the Tax Court rejected a device by which a ta:payer transferred "legal title in and to a beneficial interest in and to" certain stocl: Loretto M. Richards, 19 T.C. 366 (1952). It was observed by the third eircuit that "the factors are not the niceties of title but the controls retained by the settlor." Brown v. Commissioner, 131 F.2d 640, 641 (3d Cir. 1942).

The present discussion is limited to gratuitous transfers, but it should be observed that there is some correlation between this subject and the problem of determining when a sale of future income from property will be treated as sale of a capital asset. Fur example, the Supreme Court has held that proceeds paid a lessor upon cancellation of a lease should be treated as income rather than capital gain. Hort v. Commissioner, 313 U.S. 28 (1941). This result is consistent with holdings that assignment of future rentals from property is not effective to redirect income. See Ward v. Commissioner, 58 F.2d 757 (9th Cir. 1932) ; Clifford R. Allen, Jr., 12 T.C. 227 (1949). It has been said, however, that when all of the rights of the assignor as landlord are transferred, the assignment is effective to redirect income to the assignee. Lum v. Commissioner, 147 F.2d 356 (3d Cir. 1945). See also notes 29 and 30 infra. 
avoid the progressive features of the tax should not be able to succeed merely by showing that what he transferred could technically be categorized as property. A second deficiency arises in part from the first. Words like "ownership" and "property" are susceptible of many different meanings. Their proper import can be ascertained only by examining their rational relation to the problem they concern. Since the common law indicia of "ownership" and "property" have little rational relation to equitable tax distribution, they do not help to define the terms, and the decisions dealing with the terms in a tax context are hardly more helpful. The courts have suggested nothing more definitive than that a donor desiring to avoid income tax liability may not retain "substantial" interests or the "substance" of ownership ; ${ }^{25}$ that the motto "To be rather than to seem" must be applied ${ }^{26}$ and that the "import and reasonable construction of the taxing act" must control. ${ }^{27}$ Furthermore, if the "ownership" doctrine were consistently applied in all cases, it would open the door wide to all kinds of tax evasion. Every time any person made an anticipatory assignment-even, for example, one of wages earned in the past-he could successfully avoid tax on the income on the ground that he had transferred property. This logical extension of the doctrine has long been rejected by the courts, as it should be.

It might have been expected that the judicial denunciations of the "property" concept, coupled with its inherent deficiencies, would long since have brought about its demise. The fact is, however, that in some areas of tax law cases are still being decided on the basis that a transfer of the ownership of property is effective to redirect income from donor to donee. This has been the rationale of decisions holding that gifts of oil in place and in-oil payments are effective to redirect income from assignor to assignee. ${ }^{28}$ It likewise accounts for de-

25. See, e.g., Commissioner v. Sunnen, 333 U.S. 591, 608 (1948) ; Loretto M. Richards, 19 T.C. 366,376 (1952); Verne Marshall, 1 T.C. 442,447 (1943).

26. Doyle v. Commissioner, 147 F.2d 769, 772 (4th Cir. 1945).

27. Harrison v. Schaffner, 312 U.S. 579, 581 (1941); Lucas v. Earl, 281 U.S. 111, 114 (1930).

28. See, e.g., Porter Royalty Pool, Inc. v. Commissioner, 165 F.2d 933 (6th Cir. 1948); United States v. Spalding, 97 F.2d 701 (9th Cir. 1938) ; T. W. Lee, 42 B.T.A. 1217 (1940). Cf. Edward G. Swartz, Inc. v. Commissioner, 69 F.2d 633 (5th Cir. 1934) (assignment of rights to cut timber effectual to redirect income to the assignee). The Internal Revenue Service now takes the position that "the assignment of any in-oil payment right ... which extends over a period less than the life of the depletable property interest from which it is carved, is essentially the assignment of expected income from such property interest." I.T. 4003, 1950-1 Cuns. Bull. 10, 11. This scems clearly in accordance with the rejection of the "property" concept in other areas.

However, it was held in Lester A. Nordan, 22 T.C. 1132 (1954), that a temporary assignment of an oil payment constituted a transfer of property. The Treasury ruling was also rejected in a split decision holding that such an assignment is of a "tree" rather" than "fruit"; of "property" rather than "income." Caldwell v. Campbell, 218 1.2d 567 (5th Cir. 1955) (assignment of in-oil payments for consideration resulted in capital gains rather than ordinary income treatment). The dissenting judge observed that by the assignment of the oil payment "the taxpayer is merely collecting some of his royalty income in advance." Id. at 575. 
cisions to the effect that the transfer of an entire lease by a lessor-owner will redirect income thereunder to the assignee even though the assignor remains the owner of the leased property. ${ }^{29}$ In substance a transfer of income is there involved; in form the ownership of property is transferred. Decisions on the "property" basis persist ${ }^{30}$ notwithstanding that the broad language of Commissioner $v$. Sumnen, ${ }^{31}$ striking down an assignment of contractual rights under patents, affords a basis for expecting that no assignment of a contract would thereafter be effective to redirect income.

The vestiges of the property concept, manifested in the foregoing cases, should be eradicated. As will be shown later in some detail, ${ }^{32}$ there is little justification for permitting a taxpayer to redirect income from his own personal services to a donee, even though those services are embodied in a copyright, literary property, patent or invention. There is absolutely no justification for permitting the person owning such property to redirect part of the proceeds of it by assigning a lease or royalty agreement while retaining control of the basic property. Likewise, there seems to be no justification for saying, as some courts have, ${ }^{33}$ that gratuitous assignment of an entire lease will be

29. See, e.g., Lum v. Commissioner, 147 F.2d 356 (3d Cir. 1945); Mfidwood Associates, Inc. v. Commissioner, 115 F.2d 871 (2d Cir. 1940) (semble); Ward v. Commissioner, 58 F.2d 757 (9th Cir. 1932) (scmble). The "property" concept was also relied upon where a taxpayer transferred a valuable contract to a corporation and gave stock: to members of his family. Commissioner v. Alontgomery, 144 F.2d 313 (5th Cir. 1944). In a very few decisions, courts have relied upon this concept in cases where the donor assigned the ownership of property to a trustee. See, e.g., Afahaffey v. Helvering, 140 F.2d 879 (8th Cir. 1944). But see Wood v. Commissioner, 74 F.2d 78 (6th Cir. 1934); Loretto M. Richards, 19 T.C. 366 (1952).

30. Note, e.g., emphasis on the "property" concept in the treatment of an assignment of a contract for royalties, in Morris Cohen, 15 T.C. 261 (1950). See also notes 45 and 46 infra. In Arthur T. Galt, 19 T.C. 892 (1953), aff'd, 216 F.2d 41 (7th Cir. 1954), it was held that the assignment of a percentage of lease receipts to children of the donor was ineffective to redirect the income, but both the Tax Court and the court of appeals were careful to reserve decision on the effect of a transfer of the entire lease.

31. 333 U.S. 591 (1948). See also Burnet v. Leininger, 285 U.S. 136 (1932).

This discussion is not primarily concerned with instances in which a transferor is charged with income which he has assigned to another in a business transaction. However, principles enunciated in the cases dealing with gratuitous transfers have not infrequently been invoked in the context of arms-length transactions. The concept that where "ownership" of "property" is transferred the income from the property is taxable to the transferee has, for example, been relied upon to support an allocation of income to a wife receiving income from a trust providing for separation payments. Pearce v. Commissioner, 315 U.S. 543 (1942). But the concept was rejected where the claimed transfer of property" in trust was found to be only a transfer as security for alimony payments. Longjear $v$. Helvering, 77 F2d 116 (D.C. Cir. 1935). The same theory was invoked where a taxpayer assigned a portion of his interest in an annuity to another for a consideration. The Tax Court thought the assignor should not thereafter be taxed with the anmuity income since he had completely assigned his interest in the "property," i.c., the annuity. Estate of Laughlin, 8 T.C. 33 (1947).

32. See text at notes $45-48$ infra.

33. See cases cited note 29 supra. 
sufficient to redirect income from assignor to assignee simply because the lease is property. Neither does there seem to be any legitimate usefulness in a theory that allows a person having a right to income from minerals to transfer a royalty agreement or an in-oil payment and thus redirect income to another on the ground that he is transferring property.

It is of course true that the "property" concept might properly be applied to cases such as those where a taxpayer conveys absolute title to real estate, the rentals from which are thereafter collected by the donee. But the fact that the doctrine may be applicable in some circumstances does not demonstrate that it should be imposed in all, and the "property" concept in itself offers no indication as to when it is applicable and when it is not. An opinion from the second circuit, which has wrestled mightily with the problem, illustrates the difficulty. The court noted that:

"what is relevant to 'ownership' in determining the niceties of rights or duties under the rules concerning trust estates may need to be disregarded in applying the cruder test of taxability; in the law of trusts the cutting edge of the pertinent rule must be razor-sharp, while in income tax law, involving so sweeping a provision as Section $22(\mathrm{a})$, the helpftil image is rather that of a broad-sword."34

The scholar seeking a formula by which to predict the outcome of cases using the "property" concept might well conclude that a more appropriate judicial image would project an implement from the barnyard rather than the battlefield.

\section{Taxing Incone to the One Who Earns It}

\section{Income That Has Already Been Earned}

Courts have frequently asserted that income is taxable to the one who earns it. Thus it was said in Helvering $v$. Horst ${ }^{35}$ that

"the rule that income is not taxable until realized has never been taken to mean that the taxpayer, even on the cash receipts basis, who has fully en joyed the benefit of the economic gain represented by his right to receive income, can escape taxation because he has not himself received payment...."36

Clearly this doctrine contemplates at the very least the case of a person who owns property or has performed services, and who, before the earnings therefrom formally accrue, assigns his right to the income to another. In such a case it might well be said that the taxpayer has been vested with the right to the income at the time of the assignment, and therefore should be taxed upon it.

The doctrine that income is taxed to the one who has earned it is unquestionably established, workable law. A primary case in this area is Lucas v. Earl, ${ }^{37}$

34. Commissioner v. Buck, 120 F.2d 775, 777 (2d Cir. 1941).

35. 311 U.S. 112 (1940).

36. Id. at 116.

37. 281 U.S. 111 (1930). 
where a taxpayer was held taxable on earnings he had assigned to his wife before he earned them. A fortiori, his tax status would have been no more favorable if he had made the assignment after the income was earned though before it was paid. And so it has been held that where an employer makes payments to a trustee for the benefit of an employee and his family, the income should be taxed to the employee. ${ }^{38}$ Similarly, where an employer pays insurance premiums for the benefit of the employee's family, the employee is taxed on the premiums as income. ${ }^{39}$

The principal difficulty with the rule is that it is not consistently applied in cases where taxpayers seek to transform earnings into a capital asset. To the extent that the "property" doctrine previously discussed is applied, presumably a person might escape the tax by giving away his earnings in the guise of property. Thus, a taxpayer may earn income from sales of insurance, part of the income being paid currently as commissions and part in the form of renewal commissions to be paid in the future. Whether this right is called a chose in action or described by some other name, it is intangible property. When the owner transfers it, the property is owned by the donee. In the donee's hands it is, of course, not "earnings." Should the donor nevertheless be taxed with respect to the sums received by the donee! Has the donor assigned "earnings" or "property"? Where a donor assigns the fruits of his labor can it ever be said that what he assigns is not earnings? These questions were answered by the decision in Hclvcring $v$. Eubank, ${ }^{40}$ a thoroughly uninformative opinion holding that the donor should be taxed with respect to income arising from renewal commissions, notwithstanding a transfer of his rights therein to his wife. No suggestion was made as to the line of distinction between transfers of earnings and transfers of property. Other decisions con-

38. Comer v. Davis, 107 F.2d 355 (5th Cir. 1939); J. H. JfeEwen, 6 T.C. 1018 (1946).

39. Commissioner v. Bonwit, S7 F.2d 764 (2d Cir. 1937) ; Canaday v. Guitteau, 86 F.2d 303 (6th Cir. 1936). See also U.S. Treas. Reg. 118, § $39.22(a)-3$ (1953). Similar conclusions have been reached in similar cases without reference to this doctrine, reliance being placed on the general undesirability of tax avoidance Jones v. Page, 102 1.2d 144 (5th Cir. 1939). Occasionally donors have sought unsuccessfully to redircet incente through closely held corporations. V. U. Young, 5 T.C. 1251 (1045); Ronald Mattos, 2 T.C. 586 (1943). Other examples of the doctrine are found in Jolmson v. Lnited States, 135 F.2d 125 (9th Cir. 1943); Charles E. Rieben, S T.C. 359 (1947).

The rule has been rejected in more dubious circumstances: for example, in cases where a person directs that earnings normally paid to him should be paid instead to charity. Commissioner v. Giannini, 129 F.2d 638 (9th Cir. 1942). See also Hendricls v. Commissioner, 154 F.2d 90 (2d Cir. 1946); U.S. Treas. Reg. 118, $\$ 39.22($ a)-(2) (1953). See Charles L. Jones, 2 T.C. 924 (1943), where an assignment of annuity rights to donor's wife successfully redirected income to her.

In other cases the propriety of the rule has been acknowledged but the rule has not been applied to the facts presented. Estate of Blades, 15 T.C. 190 (1950).

40. 311 U.S. 122 (1940). An interesting case before Enbark, in which a court swught to distinguish a transfer of a chose in action from transfer of earnings in this situatiun, is Van Meter v. Commissioner, 61 F.2d 817 (Sth Cir. 1932). 
sidering the problem have been no more enlightening, although the courts have frequently enough ignored the transmutation of income from earnings to property and taxed the one who earned and then transferred the income. This result has been reached where the services eventuated in such assorted property as retirement rights, ${ }^{41}$ settlement rights arising from past services at the termination of a business relationship, ${ }^{42}$ and contractual agreements arising from services performed by the donor. ${ }^{43}$ The same result of taxing the donor has been reached in certain cases involving services rendered in the creation of property-for example, where there has been an assignment of royalties arising from patents created by the personal services of the donors ${ }^{44}$

On the other hand, taxpayers have sometimes been able to transmute the results of their personal services into property which, when transferred, insulates the donor from tax. For example, it seems clear that a farmer who gives little sheep to his daughter and then provides services by virtue of which little sheep become big sheep does not realize income thereby-the daughter is taxed on the increase in value. ${ }^{45}$ And it has been held that where a person has

41. Duran v. Commissioner, 123 F.2d 324 (10th Cir. 1941).

42. Robert Lubets, 5 T.C. 954 (1945). Such a case may lead to a remarkable result. The taxpayer here may be said to receive ordinary income; what he gave away was a substitute for ordinary income. Yet in a partnership case where he sold his partnership interest, including rights to income, he would have been considered as selling a capital asset, i.e., property, under the doctrine of Swiren v. Commissioner, $183 \mathrm{~F} .2 \mathrm{~d} 656$ (7th Cir. 1950). G.C.M. 26379, 1950-1 Cun. BuLl. 58, adopts this view. Such a transaction with respect to partnership interests is now governed by INT. REv. Cone of 1954, $\$ \S 741$, 751 , which in substance provide that the sale of a partnership interest will result in capital gain except as to unrealized receivables and inventory items. Gain attributable to these items is treated as ordinary income.

43. Strauss v. Commissioner, 168 F.2d 441 (2d Cir. 1948); Lorenz Iverson, 3 T.C. 756 (1944); Ronald Mattox, 2 T.C. 586 (1943). See also Lewis v. Rothensies, $61 \mathrm{~F}$. Supp. 862 (E.D. Pa. 1944), aff'd per curiam, 150 F.2d 959 (3d Cir. 1945). But cf. Commissioner v. O'Donnell, 90 F.2d 907 (9th Cir. 1937).

44. See, e.g., Commissioner v. Sunnen, 333 U.S. 591 (1948); Wood Process Co., 2 T.C. 810 (1943). But cf. Byrnes v. Commissioner, 89 F.2d 243 (3d Cir. 1937). It has been said that an assignor of royalties arising from use of his secret process (not a patent) could be taxed on the royalties though the contract under which they arose was assigned to another. Washington v. Commissioner, 80 F.2d 829 (2d Cir. 1936). But the Tax Court has recently held that assignment of an entire license agreement would be effective to redirect income from the assignor to the assignee. Morris Cohen, 15 T.C. 261 (1950). Perhaps the license agreement more closely resembles "property" than does a right to royalties.

45. Visintainer v. Commissioner, 187 F.2d 519 (10th Cir. 1951). See also Alexander v. Commissioner, 194 F.2d 921 (5th Cir. 1952); Edwin F. Sandberg, 8 T.C. 423 (1947). But see Hogle v. Commissioner, 132 F.2d 66 (10th Cir. 1942). It is diffictlt to rcconcile the two cases from the tenth circuit. It is even more difficult to predict the way in which the law will develop in these cases. The Commissioner has ruled explicitly that one who raises stock on the cash basis and donates it to an object of his bounty realizes income to the extent of the value of the stock at the time of the gift. I.T. 3932, 1948-2 Cum. BuLl. 7. The Tax Court has evinced no enthusiasm for this result. Estate of W.G. Farricr, 15 T.C. 277 (1950). Both I.T. 3932 and I.T. 3910, 1948-1 Cum. Bull. 15, appear to have 
embodied inventive genius in a patent, a subsequent gratuitous assignment of the patent is a transfer of property, so that income with respect to the patent is not taxable to the donor. ${ }^{46}$ This result seemingly arises from the view that a patent is an independent and definable species of property, rather than earnings. Yet this view seems to have been rejected as to contractual interests in copyrights $^{47}$ and trademarks, ${ }^{48}$ where some controls over the copyright or trademark were retained by the donor.

Another group of cases concerning the assignment of income arising from the personal services of a donor deals with partnership and quasi-partnership relations. The partnership problem is now regulated by statute, ${ }^{10}$ but the early cases have left their traces in current doctrine respecting redirection of income. If $A$ performs services for $B$ and directs $B$ to pay his wages to $C$, unquestionably $A$ receives income. Suppose, however, that $A$ performs services for which payment is made to the $A-C$ partnership, to which $C$ contributes neither capital nor services. That which would be income to $A$ in the first example would seem to be his income here. On the basis of one Supreme Court decision, Commissioner $v$. Tower, ${ }^{50}$ it was once thought that all partnership income would be taxable to $A$ in such a case except to the extent that $C$ contributed services or capital that did not originate with $A .^{51}$ The Court subsequently denied that this was the import of the Tower case, and stated that the proper

been rejected by the fifth circuit. Campbell v. Prothro, 209 F.2d 331 (5th Cir. 1954). The subject is analyzed with considerable vigor and perspicacity in Afiller, Gifts of Income and of Property: What the Horst Case Decides, 5 TAx L. REv. 1 (1949). The subject is discussed from another point of view in the text at note 63 infro. The result suggested there would seem preferable to that reached in Visintainer, supra.

46. While the cases are not squarely in point, this would seem to follow, a fortiori, from such decisions as those in which gratuitous assignments of license agreements respecting patents were held sufficient to redirect income to the assignee. Sce, e.g., Byrnes v. Commissioner, 89 F.2d 243 (3d Cir. 1937) ; Morris Cohen, 15 T.C. 261 (19:0). In the latter case, Cohen assigned certain patent interests which he had received from his employer pursuant to an employment agreement. It was held that the assignnent of these interests was the same as an assignment of wages and the assignor was taxcd with income therefrom. There were other services by virtue of which the donor obtained an intercst in a license agreement. This was transferred also. The latter transfer was held adequate to redirect income, even though it would seem that the basic income would cqually represent "earnings" from the donor's services whether embodied in a license or not. See alsy Commissioner v. Sunnen, 333 U.S. 591 (1948); Arthur J. Galt, 19 T.C. 892 (1953), aff'd, 216 F.2d 41 (7th Cir. 1954) (lease of real property).

47. Wodehouse v. Commissioner, 178 F.2d 987 (4th Cir. 1949); Sax Rohmer, 14 T.C. 1467 (1950). Contra, Wodehouse v. Commissioner, 177 F.2d $\$ 81$ (2d Cir. 1949).

48. Estate of Dodson, 1 T.C. 416 (1943).

49. INT. REv. CODE OF 1954, $\S 704$ (e), 7701 (a) (2). As to the effect in partnershiptrust cases of the incorporation of the Clifford Regulation into the statute, see note 93 infra.

50. 327 U.S. 280 (1946).

51. Some earlier cases in this area had sought to resolve the issue simply by a general reference to the doctrine that income is taxable to the one who really earns it. See, $8 . g$., Schroder v. Commissioner, 134 F.2d 346 (5th Cir. 1943); Tinkoff v. Commissioner, 120 F.2d 564 (7th Cir. 1941). 
test was whether a bona fide partnership was truly intended. ${ }^{52}$ The opinion was something less than illuminating, but it seems consistent with the general rule respecting earnings. That is, income is taxed to the one who earns it: in deciding whether income is in fact earned by a partnership or a dominant partner personally, the test in the absence of a specific statute is whether a bona fide partnership was intended. In some cases, taxpayers have tried to give donees participating interests in businesses, stopping short of formal partnership arrangements. Such quasi-partnership arrangements have met with varying success in the courts, which more often than not ignore the partnership analogy. ${ }^{53}$

The issue in the cases involving personal services is simple. Services performed for an employer should be taxable to the one who performs them even though he assigns his right to the earnings before receipt of them. And the same result would follow if the services were rendered by an independent contractor. The result should be no different when a person renders services resulting in a salable commodity such as a patent, copyright, trademark or other inventive or literary property. Courts have not yet gone so far, but there is no reason why they should not. ${ }^{54}$

52. Culbertson v. Commissioner, 337 U.S. 733 (1949). The problem is currently governed by $\S \S 704$ and 7701 (a) (2) of the Code. Note that under $\$ 704$ (c) (2) a partner performing disproportionate services for the partnership is taxed with that share of partnership income allocable to his services, if he created other partnership interests by gift. He cannot, merely because he is a partner, redirect the fruits of his labor to another partner who is the object of his bounty.

53. See cases cited note 45 supra and notes $58-60$ infra. For arrangements hold ineffective to redirect income in cases involving theater operations, see Yiannias v. Commissioner, 180 F.2d 115 (8th Cir. 1950); Wade Allen, 6 T.C. 899 (1946). Other cases holding similarly include Robert E. Werner, 7 T.C. 39 (1946); Daniel J. Fry, 4 T.C. 1045 (1945). See also V.U. Young, 5 T.C. 1251, 1257 (1945) and Ronald Mattox, 2 T.C. 586 (1943) (similar attempts involving the corporate form). An example of the doctrine in a leaseback case is Paul G. Greene, 7 T.C. 142 (1946), where the taxpayer arranged for his wife and another to form a partnership-to which she contributcd neither capital nor services-which purchased and leased to another partnership of which the taxpayer was dominant member certain equipment needed by the latter. It was held that amounts received by the wife from her partnership were taxable to the husband. But cf. Woffard v. Commissioner, 207 F.2d 749 (5th Cir. 1953). For further discussion of leasebacles, see note 87 infra.

54. In the cases here discussed, the effort is to turn earnings into property, on the theory that a gift of property is effective to redirect income while a gift of earnings is not. In a parallel line of cases the effort is to turn earnings into property or a capital asset, and then sell the property, the object being to change what would be taxable as ordinary income if received as earnings into capital which will be taxed at capital gain rates when the item is sold or exchanged. The latter cases are not within the scope of the present discussion, but it should be noted that the decisions in this capital gains area are thoroughly unrealistic, and afford no authoritative rules of sufficient dignity to control decisions respecting gratuitous anticipatory assignment of income. For a discussion of one phase of the subject, see Plumb, Tax Effect of Sales of Life Intcrests in Trusts, 9 TAx L. Rev. 39 (1953); a more comprehensive discussion is to be found in Miller, Capital Gains Taxation of the Fruits of Personal Effort, 64 YALE L.J. 1 (1954). See also note 


\section{Incone Assigned Before It Is Earned}

Where a person assigns a right to income that he has not yet earned, the assignor is taxed on the income. ${ }^{55}$ This result is desirable for the reason, among others, that the taxpayer has control of the income to be received by his assignee: that is, if the assignor performs no services, the assignee receives no income. Hence it is suggested that since the assignor controls the income it is proper to tax him with it. This doctrine appears rational enough. It is clearly part of the "control" concept generally. ${ }^{\text {"0 }}$

In summary, it may be said that the general doctrine that income must be taxed to the earner thereof is basically sound. In the cases where the taxpayer has not attempted to transform ordinary income into some kind of property such as a chose in action, it is easily applied. Where the taxpayer tries to

24 supra. There seems to be little doubt that the two lines of cases involve substantially the same problems, notwithstanding an occasional observation to the contrary. Sce cases cited note 79 infra.

The Revenue Act of 1954 provides that gain from the sale of a patent is treated as gain from the sale of a capital asset. INT. REv. Cone of 1954, $\S 1235$. The Senate Report recites: "Your committee has no intention of affecting the operation of existing law in those areas without its [the statute's] scope." S. Rep. No. 1622, 83d Cong., 1st Sess. 441 (1954). The statute contains no reference to treatrient of gratuitous assignments as transfers of property as distinguished from income. In view of the forcgoing language, no implication with respect to the latter subject may be drawn from $\$ 1235$.

55. The leading case, of course, is Lucas v. Earl, 281 U.S. 111 (1930).

56. See notes $66-68$ infra and accompanying text. The doctrine that carnings are to be taxed to the earner has also found acceptance in cases where carnings are nut transferred gratuitously. An elementary example is Leicht v. Commissioner, 137 F.2d 433 (Sth Cir. 1943), where a taxpayer was taxed with salary for services although the employer at his request applied it to discharge the employer's indebtedness to the taxpayer. A similar result was reached where the employer paid money to a corporation designated by the taxpayer, Saenger v. Commissioner, 69 F.2d 631 (5th Cir. 1934). Further support for the doctrine is found in United States v. Lynch, 192 F.2d 718 (9th Cir. 1951), where it was held that a corporation that distributed agricultural produce in liquidation and then sold it, paying the stockholders in cash, received income from the transaction. The court cited the Eubank and Horst cases, and emphasized that redirection of income can no more be accomplished by a corporate liquidation than by a direct anticipatory assignment. Substantially the same conclusion was reached in H.B. Snively, 19 T.C. 850 (1953). The same principle was applied in taxing a corporation with receipts allocated to stocliholders during liquidation, Floyd v. Scofield, 193 F.2d 594 (5th Cir. 1952). This result scems proper since the corporation is actually redirecting its earnings. This may be thought to be in conflict with the case law prior to the new Code, expressed in General Utilities \& Operating Co. v. Helvering, 296 U.S. 200 (1935), where it was held that a corporation that distributes to stockholders property that has appreciated in value does not realize income to the extent of the appreciated value. The Lyucli case, supra, may be distinguished from General Utilities, supra, on the basis that in Lymch the distribution consisted essentially of earnings rather than an unrealized increment. In a case where a bants was held taxable with respect to the value of obligations which it first wrote off and then distributed to stockholders, the majority of the court found the Horst case controlling; the dissent claimed that the General Utilities case required a decision for the bant. Commissioner v: First State Bank of Stratford, 168 F.2d 1004 (5th Cir. 1948). The Gencral C'tilitics problem is now treated by INT. REv. CoDE of 1954, $\$$ 301, 307, 311, 312. 
convert ordinary income into disposable property, courts frequently-but not always-ignore the attempted transmutation. In general the rule is, and should always be, that when a claim to income arises from earnings, it will be attributed to the earner regardless of a change in its form. This should likewise be true where services are performed on behalf of a donee, as in those cases where the donor channels profits from business operations to a donee under arrangements that fall short of a partnership. When the partnership device is used, the requirements of the law are clear under recent amendments to the Code; when those provisions are not applicable it must be ascertained whether a bona fide partnership is truly intended. However unsatisfactory the latter concept may be, it is not inconsistent with the principle that earnings must be taxed to the earner.

\section{Unrealized Increment from Property: Does It Constitute Earnings Ta.able to the Donor?}

A related problem concerns assignment of property whose value has appreciated in the donor's hands. It is clear that redirection of income from property as well as from personal services, after the right to the income is fixed, should be unavailing to avoid taxation. But the answer is not so simple when the income from the property is in the form of an unrealized increment in its value. An example will illustrate the problem: assume that $A$ buys Blackacre for farming purposes at a low price and gives it to his son twenty years later when it has doubled in value. The son subsequently sells it and takes a profit. $A$ did not retain any control of the corpus of the gift-he "cut the string." At the time of the gift he had received no income with respect to the property; there was simply an unrealized increment in it. In such a case $A$ would not be taxed on the increment, for section 1015 of the Code provides that in such cases a donee takes the donor's basis for the property. This means that when the donee disposes of the appreciated property he will be taxed on the increment; and it would be inequitable to tax the donor as well on the same increment. Section 1015 thus suggests a general policy of not treating a gift as a taxable realization by the donor of increment in property value, and of postponing taxation until the increment is realized by the donee.

But the courts have treated the donor as if he had realized the increment, when it is clear that he has earned the increment by his own efforts in improving the property or speculating in such property. In such cases it is equitable to tax the increment to the taxpayer just as if it were money earned and then assigned by him. Thus where the taxpayer actively engaged in stock exchange trading in stocks which he had given to a donee, the profits were taxed to him. ${ }^{57}$ In one case a taxpayer assigned his share of a judgment against the United States to his wife and children after collection was practically assured. He was nevertheless taxed with the income: in the words of the court, the

57. See Hogle v. Commissioner, 132 F.2d 66 (10th Cir. 1942), where the settlor of a trust was taxed on the value of such services. 
donees without effort of their own could smile in clear anticipation that "it was about to snow in their hats." 58 The same result has been reached in cases involving claims for impounded property, ${ }^{59}$ and corporate stock assigned after the donor had recovered his basis and just before the corporation was liquidated. ${ }^{60}$

Similarly, in $1 . T .3932^{\circ 1}$ the Commissioner asserted tax liability against a father who gave livestock to his son. The father's basis for the livestock was zero, since it had been raised on his farm. The tax was measured by the difference between his basis and the value of the livestock when it was given. In this case there was an additional increase in the value of the livestock after the gift to the son; and so when the son sold the livestock the problem of the son's basis under section 1015 was squarely presented. The Commissioner solved this problem by adding to the donee's basis as derived from the donor the sum of the increment that had been taxed to the latter. This seems to be a sensible solution to the problem of a two-fold increment in the value of property gratuitously assigned. Whether it is authorized under the present statute is dubious. ${ }^{62}$

It has been sensibly suggested that the entire problem of taxation of unearned increment calls for legislative consideration. ${ }^{\text {C3 }}$ If a taxpayer cannot redirect income from past or future services by anticipatory assignment, no more should he be able to redirect income by an anticipatory assignment of the un-

58. Doyle v. Commissioner, 147 F.2d 769, 772, (4th Cir. 1945). A similar result uas reached in Heyman v. Commissioner, 176 F.2d 389 (2d Cir. 1949), in which the court relied in part on the Doyle decision, supra.

59. Estate of S.W. Anthony, 5 T.C. 752 (1945), aff'd, 155 F.2d 980 (10th Cir. 1946).

60. Tatem Wofford, 5 T.C. 1152 (1945). But sec Commissioner v. Montgomery, 144 F.2d 313 (5th Cir. 1944); Apt v. Birmingham, 89 F. Supp. 361 (N.D. Iowa 1950); Theodore D. Stern, 15 T.C. 521 (1950).

Closely allied to these cases are those involving assignment of income which has arisen or is expected to arise from construction contracts. Income has been successiully redirected where a taxpayer obtained a construction contract, assigned it to a close-held corporation for stock and gave the stock to his children. P. O'B. Montgomery, 1 T.C. 1000 (1943). But cf. Jones v. Page, 102 F.2d 144 (5th Cir. 1939) (rejecting a somewhat similar device where the contract was assigned to a trustee). On the other hand, where a corporation obtained the contract and assigned its right to collect money under the contract to the stockholders, who in turn assigned their right to others, the income was nevertheless taxed to the steckholders. Heyman v. Commissioner, 176 F.2d 359 (2d Cir. 1949). See also Standard Paving Co. v. Commissioner, 190 F.2d 330 (10th Cir. 1951); National Contracting Co. v. Commissioner, 105 F.2d 488 (8th Cir. 1939). The same connclusion was reached in substance in the case of Jud Plumbing and Heating Co. r. Commissioner, 153 F.2d 681 (5th Cir. 1946). However, Jud Plumbing was disposed of completely on the general requirements of Int. Rev. Code of $1939, \$ \S 41-45$ that the return of a taxpayer must clearly reflect income. This factor is frequently emphasizcd in these cases. See, e.g., Standard Paving Co. v. Commissioner, supra.

61. 1948-2 Cux. BuzL. 7. A forerunner of this ruling, relating to charitable contributions, is I.T. 3910, 194S-1 Cuns. Brz.. 15.

62. See the discussion of this type of case at note 45 supra and accompanying test.

63. Niller, Gifts of Income and of Property: What The Horst Case Decides, 5 Tax L. REV. 1 (1949). 
earned increment on property. But until legislative action is taken, it appears that the furthest the courts will go is to tax to the donor as income only such items as are identifiable as arising from his personal services. This result should follow if he speculates in the purchase and collection of a claim, or in the raising of livestock, or in the promotion of oil recovery. Profits arising from such activities are in substance personal earnings which are redirected to the donee, and which should not be permitted to masquerade as unrealized increment. But where property is assigned with an unrealized increment that arose from a general and normal increase in the value of property, as distinguished from speculative gains depending on the talents and services of the donor, the donor will not be taxed on the increment. In the absence of legis. lative clarification, this line of distinction must be developed by the courts on a case-by-case basis. The difficulties presented are worth tackling in order to restrain tax avoidance through gratuitous assignments of items essentially equivalent to earnings.

\section{"Control" over Income or the Source of Income as a Ground for Taxing THE Donor}

Another concept used by the courts to determine the effectiveness of a gratuitous anticipatory assignment of income turns on the extent of the control retained by the transferor over either the income or the source of income assigned. As the Supreme Court has recently put it, the crucial question is "whether the assignor retains sufficient power and control over the assigned property or over receipt of the income to make it reasonable to treat him as the recipient of the income for tax purposes." 64 As this language indicates, cases dealing with "control" over income to be received in the future by the assignee fall into two groups. One group involves the taxpayer who gives income to another but retains some controls over the time and manner in which the income will vest, or whether it will vest at all. The second-and much more important-group of cases deals with income that arises from property transferred as a gift by a donor. It has already been noted that some courts have said that where ownership of property is transferred, income therefrom is taxable to the donee. ${ }^{65}$ The "control" concept is actually a modification and refinement of the "ownership" view. Simply stated, this concept means that where a taxpayer gives away the ownership of property he is nevertheless taxable on the income from the property if he retains substantial control over it. The following discussion concerns the history, logic, and current effectiveness of both facets of the "control" concept.

\section{Control over Income from Future Services}

We have already considered transfers of amounts previously earned by a donor. Such sums are taxable to the donor without regard to any controls

64. Commissioner v. Sunnen, 333 U.S. 591, 604 (1948).

65. See text pp. 995-1000 supra. 
retained by him. A different problem is presented by those cases where an assignment of future income from services is involved. The lending case in this area is Lucas $v$. Earl, ${ }^{60}$ where a husband who had assigned to his wife income from services which he was to perform after the assignment was taxed with respect to such income. One ground for decision suggested by the court was that ultimate control over the income was held by the donor: "it is somewhat hard to say that the last step in the performance of those contracts could be taken by anyone but himself alone." 67 Other cases have adopted the same principle in somewhat more explicit terms. In one early case, for example, it was specifically held that the donor of future earnings should be taxed as though he received the income, since the earnings "were necessarily left within the assignor's power, his continued activity being a condition upon them."0s These cases demonstrate that an assignment of income to accrue from future services is clearly unavailing to redirect income from the assignor. More than one reason might be assigned for this result. The reason usually given is valid and sufficient: that the donor can perform the services or not as he vishes. Thus it is in his power to cause income to be paid to the donee or not to cause it to be paid. When he retains such complete control over income from his services it is appropriate to tax the income to him notwithstanding the assignment.

\section{Assignment of Interests in Life Estates and Similar Rights to Income}

There is a group of cases where the donor has only a right to income, and assigns that. Such cases frequently involve a life beneficiary of a trust who assigns all or some part of his interest to another. Of course, in these circumstances he retains no control over the corpus from which the income arises, since all he ever had was a right to the income, and powers purely incidental to that right. It might very well be argued that the entire amount of the income should be taxed to the donor: if he had carned a right to income to be paid in the future and then assigned that right he would be taxed notwithstanding the assignment. But it can also be argued that no tax at all should thereafter be assessed against the donor: if he had owned and given away Blackacre instead of his life estate, the gift would not involve tax liability to the donor from future use or sale of the property. An uneasy compromise between these views is made possible by the "control" doctrine: it can be said that if a donor assigns his entire interest in a life estate he has relinquished all control over the income, and so effectively redirected it to his donee for tax purposes; however, where he assigns only a portion of the income to which he is entitled, retaining control of the remainder, it may then be said that he has not parted

66. 281 U.S. 111 (1930).

67. Id. at 114 .

68. Matchette v. Helvering, 81 F.2d 73, $74-75$ (2d Cir. 1936). See also Rossmore v. Commissioner, 76 F.2d 520 (2d Cir. 1935); Shanley v. Bowers, 81 F.2d 13 (2d Cir. 1936) (dicturn). 
with anything except a temporary or partial right to income from the life estate which he retains.

So it may be argued that the income from a life estate should be taxed to the donor unless he has relinquished his entire "control" of the estate-i.c., in substance transferred the entire life estate. The courts have in fact adopted this view, ${ }^{69}$ but the cases furnish little guidance in predicting the outcome of future decisions. Two basic questions have been left unanswered: (1) for how long the donor's control must be relinquished in order to shift the incidence of the tax; and (2) whether the doctrine applies only to income received from a trust or from property on a year-to-year basis. The Supreme Court has said with respect to the time of control:

"We think that the gift by a beneficiary of a trust of some part of the income derived from the trust property for a period of a day, a month or a year involves no such substantial disposition of the trust property as to camouflage the reality that he is enjoying the benefit of the income from the trust of which he continues to be the beneficiary. ..." ."70

And the Court further observed respecting general applicability of the rule:

"Unless in the meantime the difficulty be resolved by statute or treasury regulation, we leave it to future judicial decisions to determine precisely where the line shall be drawn between gifts of income producing property and gifts of income from property of which the donor remains the owner, for all substantial and practical purposes."71

The Court's formulation is too loosely stated to provide a practical and predictable criterion for the incidence of taxation: in each case a court must cletermine whether the donor has made a "substantial disposition" of his interest so that in "reality" he is not "enjoying the benefit of the income from the trust of which he continues to be the beneficiary."

In addition, the Court's approach is an unfortunate compromise. Under Lucas $v$. Earl a taxpayer cannot minimize his tax by an anticipatory assignment of earnings from personal services. In contrast, under this doctrine he would sometimes be permitted to minimize his taxes by an anticipatory assignment of a life interest in earnings from property. The Court in the foregoing quotation seems to justify this result by holding that earnings are always "income," while a life estate is "property," and a transfer of "property" is effective to redirect income. If, as the courts have said, taxation is not to be governed by conveyancing concepts, it is hard to justify the persistence of the distinction between assignment of earnings and assignment of income from a life estate.

69. Harrison v. Schaffner, 312 U.S. 579 (1941) ; Falk v. Commissioner, 189 F.2d 806 (3d Cir. 1951); Stix v. Commissioner, 152 F.2d 562 (2d Cir. 1945); Mallinckrodt v. Nunan, 146 F.2d 1 (8th Cir. 1945). The so-called "Mallinckrodt rule" has been incorporated in $\S 678$ of the 1954 Code. See cases cited in notes 75-81 infra.

70. Harrison v. Schaffner, 312 U.S. 579, 582-83 (1941).

71. Id. at 583-84. 
Nevertheless, the Supreme Court decisions cannot be argued away, and they seem to have adopted the compromise view. There is some ethical justification for the compromise. If the donor "cuts the string" on his gift it seems proper to relieve him of tax; if the term of the assignment or other circumstances demonstrate that he still retains power to exercise substantial control or indicia of ownership over what he purports to give away, the income should be taxed to him. Solving the problem by judicial inclusion and exclusion here may be slow but it is not impossible; and it currently appears to be the only predictable line of approach to these cases in the absence of specific statutory provisions.

\section{"Control" over Past Income from Properly}

It has been noted that where a right to income from personal earnings has arisen, the holder of that right cannot minimize his tax by redirecting the income to another; for income is taxed to the one who earns it. The same result should, of course, follow in the case of earnings from property owned by the taxpayer. As to earnings which have arisen from property, the cases demonstrate that the two rules are coextensive. Income from property was involved when the Supreme Court observed that "the power to dispose of income is the equivalent to ownership of $\mathrm{it}^{\text {" }} \mathrm{T2}$ and that "income that is subject to a man's unfettered command ... may be taxed to him as his own income, whether he sees fit to enjoy it or not."'ד3 No reason exists, in logic or precedent, for distinguishing between assignment of income from earnings and income from property in these circumstances. None is made in the cases.

\section{"Control" over Future Income from Property"}

As to control of future earnings from property-as distinguished from control of the property itself-the principal cases arise in the trust field. Under the "Clifford Regulation" 74 -and now under sections 674 and 676-a settlor who retains the power to substitute himself as beneficiary or change the beneficiaries is considered taxable on the income as though he received it. A random selection of cases in the area illustrates the application of this principle prior to the adoption of the new Code. The "control" doctrine was emphasized where income was taxed to the respective donors of crossed trusts who retained controls over the income, ${ }^{75}$ and frequently has been invoked to impose tax on persons having power to direct trust income to themselves. ${ }^{70}$ It is like-

72. Helvering v. Horst, 311 U.S. 112, 118 (1940). Here, interest cuupons wure detached from bonds and given to the donee after the interest had in effcct been earned, but immediately before the due date of the coupons.

73. Corliss v. Bowers, 281 U.S. 376, 378 (1930). See also Austin v. Commissioner, 161 F.2d 666 (6th Cir. 1947); Anthony's Estate v. Commissioner, 155 F.2d 980 (10h Cir. 1946).

74. U.S. Treas. Reg. 118, \$39.22(a)-21 (1953).

75. Edward E. Bishop, 4 T.C. 862 (1945).

76. Clearly where a person has the power to take income from a trust at his discretien by revocation or otherwise, that income is taxed to him whether he takes it or nut, subject 
wise invoked in cases where a donor reserved effective control over payment of dividends previously assigned to a donee. ${ }^{77}$ Another element of "control" in cases involving trusts is present where the grantor retains the right to change the beneficiaries of a trust, by naming anyone save himself. The latter device has proved successful in some cases and unsuccessful in others. ${ }^{78}$ It should be unsuccessful in all..$^{70}$

In sum, the cases dealing with assigned income in terms of control fall into patterns which are logical and reasonably complete. The doctrines arising from these patterns are relevant to an equitable distribution of the tax burden. They have been reasonably consistent, and have provided adequate guides by which taxpayer and Commissioner may fairly predict the tax consequences of typical and recurrent transactions.

to the qualifications of the Blair and Schaffiter cases. Grant v. Commissioner, 174 F.2d 891 (5th Cir. 1949) ; Bunting v. Commissioner, 164 F.2d 443 (6th Cir. 1947); Entery v. Commissioner, 156 F.2d 728 (1st Cir. 1946); Whitehead v. Commissioner, 148 F.2d 718 (4th Cir. 1945) ; Frank v. Commissioner, 145 F.2d 413 (3d Cir. 1944); St. Louis Union Trust Co. v. United States, 143 F.2d 842 (8th Cir. 1944); Hyman v. Nunan, 143 F.2d 425 (2d Cir. 1944); Eleanor M. Funk, 14 T.C. 198 (1950); Adolphus Busch, IIt, 3 T.C. 547 (1944). This rule is incorporated in the 1954 Code at $\$ \$ 674,676,678$. See also cases cited note 69 supra.

77. Hyman v. Nunan, 143 F.2d 425 (2d Cir. 1944); Choate v. Commissioner, 129 1F.2d 684 (2d Cir. 1942) ; Bishop v. Shaughnessy, 95 F. Supp. 759 (N.D.N.Y. 1951) ; B.O. Mahaffey, 1 T.C. 176 (1942). The result in the Horst case directly supports such a conclusion. Cf. Van Sciver v. Rothensies, 122 F.2d 697 (3d Cir. 1941).

78. Compare Commissioner v. Bateman, 127 F.2d 266 (1st Cir. 1942); May Chandler Goodan, 12 T.C. 817 (1949); Carman v. United States, 75 F. Supp. 717 (Ct. Cl. 1948), with Steckel v. Commissioner, 154 F.2d 4 (6th Cir. 1946); George v. Commissioner, 143 F.2d 837 (8th Cir. 1944); Hyman v. Nunan, 143 F.2d 425 (2d Cir. 1944).

79. This device will prove successful hereafter only if the requirements of INT. Luv. CODE of 1954, § 674 are met.

Cases not infrequently arise where there is an anticipatory assignment for a considcration, of earnings that the assignor might otherwise have received from property. These cases apply the same rules as the cascs involving gratuitous transfers. For example, the assignor has been taxed where he assigned future income from royalties to his attorney, Lansill v. Burnet, 58 F.2d 512 (D.C. Cir. 1932); or as trustce directed a corporation to pay dividends directly to beneficiaries, Muir v. Commissioner, 182 F.2d 819 (4th Cir. 1950). Likewise, capital gain on stocks sold by a mortgagee and applied on the mortgagor's debt was taxed to the mortgagor. Cooperative Pub. Co. v. Commissioner, 115 F.2d 1017 (9th Cir. 1940). See also Maurice A. Mittelman, 5 T.C. 932 (1945). A leading case in this area is United States v. Boston \& Maine R.R., 279 U.S. 732 (1929), where a lessor was taxed with income which accrued to it because the lessee paid taxes owcd by the lessor. See also Commissioner v. Western Union Tel. Co., 141 F.2d 774 (2d Cir. 1944). Under the 1954 Code lease problems are governed in part by $\& 110$. Another leading case is United States v. Joliet \& Chicago R.R., 315 U.S. 44 (1942), imposing tax on a corporation with respect to amounts paid to its stockholders at the request of the corporation. See note 56 supra. It has been suggested, however, that the same doctrines should not be applied to anticipatory assignments of income that are gratuitous and those that are not. Donnelley v. Commissioner, 101 F.2d 879 (7th Cir. 1939) ; Commissioner v. First State Bank of Stratford, 168 F.2d 1004, 1012 (5th Cir. 1948) (dissent) ; Estate of Latighlin, 8 T.C. 33,45 (1947) (concurring opinion). 


\section{"Control" as Retention of Powers over the Corpus}

During the discussion of the "property" concept, reference was made to the nature of the problems that arise when a taxpayer assigns property to a donee but retains substantial controls over the corpus. ${ }^{50}$ Since the donor has patently parted with property, it might be urged that subsequent income from that property should be taxed to the donee. This result would seem to follow even though the donor retained substantial controls approximating the sum total of ownership but short of legal title to the property from which the income arises. The same result would also seem to follow as a matter of logic if he gave only income from the property, since the right to income is itself a species of property. The deficiencies of this concept-which would make virtually any assignment effective for tax purposes-are such that the courts have sought other tests of taxability more relevant to equitable distribution of the tax burden.

One obvious modification of the "property" concept is expressed in the view that a taxpayer may not effectively redirect income to another for tax purposes if he retains substantial control over the basic property from which the income arises. Sometimes this view is expressed in simple terms of "control," as in the observation that "where the donor retains control of the trust property" the income is taxable to him although paid to the donee." ${ }^{\text {11 }}$ In other cases it is emphasized that the controls and powers retained by the donor may be such as to make it proper to treat him as the owner.2 Sometimes both aspects are emphasized. ${ }^{83}$ In all cases the distinction from the "property" concept is manifest: the retention of powers and control over a corpus by a donor may frustrate redirection of income to a donee even though some kind of ownership of some kind of property passes to the latter.

80. See text at note 17 supra.

81. Helvering v. Horst, 311 U.S. 112, 119 (1940). See also Brown v. Commissioner, 131 F.2d 640,641 (3d Cir. 1942): "The factors are not the niceties of title but the controls retained by the settlor." In the gift and leaseback context, see White v. Fitzpatricl, 193 F.2d 398, 400 (2d Cir. 1951) : "The sole practical effect of these transactions, therefore, was to create a right to income in the wife while leaving untouched in all practical reality the husband-donor's effective dominion and control over the properties in question."

82. DuPont v. Commissioner, 289 U.S. 685 (1933).

83. See Helvering v. Clifford, 309 U.S. 331, 335 (1940):

"[T] he short duration of the trust, the fact that the wife was the beneficiary, and the retention of control over the corpus ... all lead irresistibly to the conclusion that respondent continued to be the owner for purposes of $\$ 22(a)$.

"So far as his dominion and control were concerned it seems clear that the trust did not effect any substantial change. In substance his control over the curpus was in all essential respects the same after the trust was created, as before. The wide powers which he retained included for all practical purposes most of the control which he as an individual would have. . .."

Similarly, in White v. Fitzpatrick, 193 F.2d 398, 401 (2d Cir. 1951), it was suggested that a donor who transferred interests in property should nevertheless be taxed on the income therefrom since there was a "transfer, in effect, of the right to receive income and the retention of those complex of 'use rights' which are usually compressed in the term 'ownership.' " 
The "control" doctrine has been applied to numerous cases. In some of the earlier decisions it was used to frustrate attempted redirection of income through family partnerships. ${ }^{84}$ Transfers of interests in literary properties ${ }^{85}$ and in patents ${ }^{80}$ have been held ineffective to redirect income under this theory. The doctrine has likewise been invoked to strike down arrangements by which a taxpayer assigns property to a member of his family and thereafter makes payments to him as rental or royalty with respect to the property. ${ }^{87}$ Yet another illustration of the operation of the rule is a case where a taxpayer sold stock to a son who borrowed money for payment from the father's bank. Although the father did not own the stock it was held that the dividends therefrom were taxable to him rather than the son. The court drew a distinction between an intention "actually to divest himself of beneficial ownership" and an intention "to create the appearance of a genuine transfer so as to avoid or reduce the payment of income taxes while really maintaining control of the property. . . ." In cases where a donor has put property in trust but retained control over it in some measure, it has also been said that the power to dispose of income is

84. M.M. Monroe, 7 T.C. 278 (1946); Daniel J. Fry, 4 T.C. 1045 (1945). But sce Albert T. Felix, 21 T.C. 794 (1954). The general subject of partnerships is considered at notes 49-53 stpra and accompanying text.

85. Wodehouse v. Commissioner, 178 F.2d 987 (4th Cir. 1949). Sce Sax Rolumer, 14 T.C. 1467 (1950). But see Wodehouse v. Commissioner, 177 F.2d $8 \$ 1$ (2d Cir. 1949).

86. Commissioner v. Sunnen, 333 U.S. 591, 608 (1948) :

"The taxpayer's purported assignment to his wife of the various license contracts may properly be said to have left him with something more than a memory. He retained very substantial interests in the contracts themselves, as well as power to control the payment of royalties to his wife, thereby satisfying the various criteria of taxability set forth in the Clifford-Horst group of cases."

87. White v. Fitzpatrick, 193 F.2d 398 (2d Cir. 1951); Dickey v. Burnet, 56 F.2d 917 (8th Cir. 1932); Estate of Dodson, 1 T.C. 416 (1943). The Commissioner now seeks to control this device by denying a deduction for amounts paid as royalty or rentals pursuant to such arrangements, on the theory that the donor properly should be treated as though he were still the owner of the property. Rev. Rul. 54-9, 1954-1 Cun. Buht. 'The issue, however, is far from settled. See Brown v. Commissioner, 180 F.2d 926 (3d Cir. 1950); Skemp v. Commissioner, 168 F.2d 598 (7th Cir. 1948). For a comprehensive and penetrating study of the problem, see Cary, Current Tax Problems in Salc, or Gift, and Leaseback Transactions, 62 HARv. L. REv. 1 (1948). Cases upholding the taxpayer in this area do not reject the "control" concept as here applicable. They just ignore it. For a case turning on partnership arrangements involving sale and leaseback, see Albert ' $T$ ". Felix, 21 T.C. 794 (1954).

88. Gouldman v. Commissioner, 165 F.2d 686, 689 (4th Cir. 1948). In another calie similar in effect the court did not relate its decision to the existence of control over property but rather to the existence of a pretended transaction. In that case a husband gave his wife money which she put in trust to be loaned back to him. The court concluted that the "interest" paid thereon was actually a gift, since the husband did not in fact give the money but only gave the interest. Johnson v. Commissioner, 86 F.2d 710 (2d Cir. 1936). Since Sunnen v. Commissioner, 333 U.S. 591 (1948), it may be hoped that assignments of any kind of contract with respect to basic income producing property retained by the donor will be ineffective to redirect income from cionor to donee. 
the equivalent to ownership of it. 89 The "control" concept was likewise used in striking down an arrangement whereby corporation stockholders gave their wives stock with very limited rights; it was held that amounts paid to the wives should be taxed to the husbands. ${ }^{90}$ Assignment of rentals has been treated in the same way. ${ }^{91}$

Leaving to one side the cases involving assignments of patents, copyrights and trademarks as such, it seems clear that the "control" doctrine should be applicable to assignments of subsidiary rights with respect to such properties. That is, if a taxpayer retains substantial interests in such property as a patent, even a complete disposition of a contract or agreement related thereto should not serve to redirect income arising out of the patent. This result certainly should follow if, as the Supreme Court has so frequently stated, property concepts are irrelevant in this area. The rule to be adopted is illustrated by the Sumen case, ${ }^{92}$ where it was emphasized that control retained by the donor over the basic property was sufficient to frustrate redirection of income. Such a rule ought equally to apply to assignments of rental agreements where the basic property rented is retained by the donor.

This raises the question of how the courts should treat a donor who gives away a life estate in Blackacre but retains the reversion. The answer should be that if the donor does not in fact retain any control over the property except that which he normally would have as reversioner, then he has divided his interest just as though he had given the donee in fee a physical portion of Blackacre. But where he retains other substantial rights with respect to the entire property, whether as controls, use rights or other indicia of ownership, income from the property should be taxed to him.

Under just what circumstances it will be found that a person has retained

89. See, e.g., Steckel v. Commissioner, 154 F.2d 4 (6th Cir. 1946); Ferdinand A. Bower, 10 T.C. 37 (1948) ; I.A. Wyant, 6 T.C. 565 (1946). See also Lowery v. Helvering, 70 F.2d 713 (2d Cir. 1934) (no control retained; donor escapes taxation).

90. Anderson v. Commissioner, 164 F.2d 870 (7th Cir. 1947); Overton v. Commissioner, 162 F.2d 155 (2d Cir. 1947); Sewell v. United States, 73 F. Supp. 957 (Ct. Cl. 1947). The same result has been reached in a trust arrangement. Iyman A. Stanton, 14 T.C. 217 (1950). See also Loretto M. Richards, 19 T.C. 366 (1952), where a ta:payer assigned to a trustee "legal title" to a "beneficial interest" in stock lie owned. All income from the stock was taxed to the taxpayer because he retaincd "substantial and important attributes of ownership of the stock." Id. at 376.

A somewhat dubious case is Lewis v. O'Malley, 49 F. Supp. 173 (D. Neb. 1943), where an unclear opinion suggests that a stockholder might be taxed on income arising from a corporate liquidation for the reason that he controlled the corporation. Referente was made to the doctrine that incone subject to the unfettered command of an individual was taxable to him whether he enjoyed it or not. See also Bishop v. Shaughnessy, 195 F.2d 683 (2d Cir. 1952).

91. "Petitioner has retained everything except the right to receive fractions of the income for a term of years." Arthur T. Galt, 19 T.C. 892, 904 (1953), aff'd, 216 F.2d 41 (7th Cir. 1954). See alsò J.E. Vincent, 19 T.C. 501, 527 (1952). But sce Edward G. Swartz, Inc. v. Commissioner, 69 F.2d 633 (5th Cir. 1934).

92. Commissioner v. Sunnen, 333 U.S. 591 (1948). 
such control over property from which income arises as to be taxable thereon cannot be predicted with certainty. It has been noted that the Supreme Court has specifically left the line to be drawn by future decisions ; ${ }^{13}$ but in drawing this line, the courts are not left entirely without guidance or direction. There are special statutory sections dealing with the redirection of income through trust devices, ${ }^{94}$ and it would seem proper that the standards applicable to trust devices should be taken as guides in the cases involving devices other than trusts. ${ }^{95}$ The principal distinction between the two is that in the trust arrangement a transferor may seek to maintain control of the property by placing control of the corpus in a third person who is subject to his will. This avente is not open to the person who transfers property directly to a donee but nevertheless seeks to retain control of it. But if the transfer is made under such circumstances-familial or other-that the donor as a practical matter may be expected to dominate the donee, this should obviously be a factor in determining whether the donor should be taxed on income arising from the corpus. The amount of the control retained by the donor is material no matter which device the donor used to redirect his income: the trust device offers more opportunities for retaining controls over property ostensibly given away, and for that reason it has been the subject of extensive statutory regulation.

In drawing the line of taxability in terms of "control," the courts will be given direction by a governing principle which is-unlike the "property" con-

93. See text at note 71 supra.

94. INT. REv. CODE of 1954 , $\$ 672-75$. It should be noted that although these new provisions of the 1954 Code embody many features of the "Clifford Regulation," there is no corresponding enactment of statutory criteria regarding the anticipatory assignment of income by non-trust devices. These criteria are quite obviously left to the courts for a casc by case determination of what constitutes income. The Senate Finance Committee Report with respect to the new Code recites in part that no items of a trist shall be included in the income of a grantor by reason of $\S 61$. S. Rep. No. 1622, $83 \mathrm{~d}$ Cong., $2 \mathrm{~d}$ Sess. 365 (1954). This statement is elaborated as follows:

"However, this provision does not affect the principles governing the taxability of income to a grantor or assignor other than by reason of his dominion and control over the trust. Thus, this subpart has no application in situations involving assignments of future income to the assignor, as in Lucas v. Earl (281 U.S. 111), Harrison v. Schaffner (312 U.S. 579), and Helvering v. Horst (311 U.S. 112), whether or not the assignment is to a trust; nor are the rules as to family partnerships affected by this subpart. This subpart also has no application in determining the right of a grantor to deductions for payments to a trust under a transfer and leaseback arrangement."

95. Helvering v. Clifford, 309 U.S. 331 (1940), the leading case dealing with trusts, emphasized that the essential factors to be weighed in determining whether the settlor of a trust was taxable with respect to the income received by it were: the term of the trust, the closeness of the relationship between donor and donee, and the degree of control retained by the settlor over income and corpus. Clifford has frequently been cited in non-trust cases; and the Horst, Hort and Schaffner cases, which involved assignments directly to the donees, have frequently been referred to in trust cases. As the Court remarked in Schaffner, there is no reason for any distinction in principle between the two types of cases. Harrison v. Schaffner, 312 U.S. 579, 582 (1941). 
cept - meaningful in relation to the basic purpose of equitable and practical administration of the revenue laws.

\section{Concrusion}

There are two current theories which, though popular, are thoroughly inadequate to establish sound rules of taxation where gratuitous anticipatory assignments of income are concerned. The "flow of satisfactions" concept proves too much: if it were literally adopted every transfer of income-producing property would create tax liability in the donor measured by the amount of the subsequent income even if the donor "cut the string" completely. This cannot be the law. In contrast, the concept that income follows ownership of property proves too little. Everything capable of transfer may be said to be property ; anticipatory assignments would always be successful if it were necessary to prove only that there was a transfer of property when the anticipatory assignment was made.

On the other hand, the rule that income must be taxed to the person who earns it has been applied with logic and consistency in most cases and is a helpful guide through the decisions respecting anticipatory assignment of income. It has not been-although it should be-applied in all cases where donors embody their earnings or their personal services in capital assets which they gratuitously assign. The basic principle of tax liability in this area arises from the concept that control by the donor over income or the source of income assigned requires that the income be taxed to him. Judicial understanding of and adherence to the last two doctrines will lead to equitable and predictable results in cases involving gratuitous anticipatory assignments of income. 


\section{THE YALE LAW JOURNAL}

\begin{tabular}{llr}
\hline Volume 64 & JUNE, 1955 & Number 7 \\
\hline
\end{tabular}

\begin{tabular}{|c|c|c|}
\hline & $\begin{array}{c}\text { Jerome A. COHEN } \\
\text { Editor-in-Chief }\end{array}$ & \\
\hline $\begin{array}{l}\text { BARRY R. BRYAN } \\
\text { Article and } \\
\text { Book Review Editor }\end{array}$ & $\begin{array}{l}\text { William H. Dempsey, Jr. } \\
\text { Thomas F. Nelson } \\
\text { Gordon B. SpIvack } \\
\quad \text { Note and Comment Editors }\end{array}$ & $\begin{array}{l}\text { GERALD WALPIN } \\
\text { Managing Editor }\end{array}$ \\
\hline IRVING J. Alter & ROBERT J. FIARRIS & Stephen J. Pollak \\
\hline Peter W. Anson & George C. Hastings & MARVIN N. RIMM \\
\hline RoBert W. BEREND & IRA MichaEl HEYMan & Bernard S. Roduins \\
\hline DANIEI M. Berger & AlEXaNDER P. HofFManN & Noruert A. Schlet \\
\hline Murry D. Brochin & Charles D. IsaAC & RAYMoNd M. SHaINUERG \\
\hline Thomas N. CARRUTHERS, JR. & DAVId B. IsBELL & W ALTER E. SHUTTLEWORTH \\
\hline Donald J. CoHn & LAWRENCE R. KLEIN & JEANNE RITCHIE SILVER \\
\hline John W. Colleran & NOEL ARNOLd LEVIN & MONROE SilverRMAN \\
\hline ALAN P. COLODNY & Charles S. MEChEM, JR. & ROBERT J. SISK \\
\hline EduUnd V. Conway & RALPH C. MENAPACE, JR. & ARLEN Specter \\
\hline Gerald M. DoppelT & Edward A. MILLER & MELVIN StEIN \\
\hline S. GoRDON ELKINS & JoN O. Newaran & JoHn SUBAK \\
\hline JoEL M. FEINBERG & LAWRENCE NEWMAN & CHARLES H. VEJVODA \\
\hline JOSEPH M. FIELD & MARTIN OPPENHEIMER & ROGER A. WELCH \\
\hline BARRY H. GARFINKEL & Otis P. Pearsall & HOWARD P. WILLENS \\
\hline Charles S. Haight, Jr. & Richard H. Pershan & GEORGE C. ZACHARY \\
\hline
\end{tabular}

Marie McMahon

Business Secretary

\section{OWEN J. ROBERTS}

The YALE LAw JouRNaL mourns the death of

Owen J. Roberts, Retired Associate Justice of the United States Supreme Court.

\section{CONTRIBUTORS TO THIS ISSUE}

Walter Adanss. A.B. 1942, Brooklyn College; M.A. 1946, Ph.D. 1947, Yale University. Associate Professor of Economics, Michigan State College. Member, Attorney General's National Committee to Study the Antitrust Laws.

RalpE S. RIce. B.S. 1929, Northern State Teachers College, Aberdeen, South Dakota; LL.B. 1932, University of South Dakota; LL.M. 1940, Harvard University. Professor of Law, University of California, Los Angeles. Co-Editor, NAvy State ANd local TAX Manual. 